\title{
Microbiological Status and Nutritional Composition of Spices Used in Food Preparation
}

\author{
Khalil I. Ereifej', Hao Feng', Taha M. Rababah'2, Sufyan H. Tashtoush'2, \\ Muhammad H. Al-U'datt ${ }^{2}$, Ghaid J. Al-Rabadi ${ }^{3}$, Peter Torley ${ }^{4}$, Malek Alkasrawi ${ }^{5}$ \\ ${ }^{1}$ Department of Food Science and Human Nutrition, University of Illinois, Urbana-Champaign, Urbana, USA \\ ${ }^{2}$ Faculty of Agriculture, Jordan University of Science and Technology, Irbid, Jordan \\ ${ }^{3}$ Department of Animal Production, Faculty of Agriculture, Mutah University, Al-Karak, Jordan \\ ${ }^{4}$ School of Applied Science, RMIT University, Melbourne, Australia \\ ${ }^{5}$ Engineering Department, Stevens Point University of Wisconsin, Stevens Point, USA \\ Email: ereifej@just.edu.jo, kereifej@illinois.edu
}

Received 7 August 2015; accepted 20 September 2015; published 23 September 2015

Copyright (C) 2015 by authors and Scientific Research Publishing Inc.

This work is licensed under the Creative Commons Attribution International License (CC BY).

http://creativecommons.org/licenses/by/4.0/

(c) (i) Open Access

\begin{abstract}
The present study showed significant initial microbial load, as well nutritional value of ten spices used widely across the world in food preparation. The microbiological tests demonstrated that sumac and cloves had the highest antimicrobial activity with respect to total plate counting and spore forming count. Results showed that chemical composition of the spices and herbs varied significantly. Dry matter content ranged between $83.6 \%$ and $92.4 \%$. The highest ash content $10.4 \%$ was found in sweet cumin, protein $21.2 \%$ in cumin, fat $19.7 \%$ in sumac, fiber $59.2 \%$ in turmeric and carbohydrates $27.3 \%$ in sumac. These spices were also differing in their minerals content. Substantial amounts of $\mathrm{Ca}, \mathrm{Na}, \mathrm{K}$ and $\mathrm{Mg}$ were found, while $\mathrm{Cu}, \mathrm{Fe}, \mathrm{P}, \mathrm{Mn}$ and $\mathrm{Zn}$ were present in trace amounts in all investigated spices.
\end{abstract}

\section{Keywords}

Microbial Status, Minerals, Proximate Chemical Composition, Spices

\section{Introduction}

The role of plants in human health has extensively revealed due to the emergence of numerous advancements in the medicine and nutrition disciplines. The awareness of the benefits of plants in food as wealthy additives poses researchers to pursue for discovering the influence of such ingredients to the health of the human beings [1] [2]. 
Spices and herbs are well known food ingredients, which enhances the flavor and aroma of the supplemented foods. Botanically, spices are one class of the aromatic plants; they are mainly present in the tropical provinces. Generally, spices could be either as seeds, flowers or leaves [3]. On the other hand, herbs are fragrant and nonwoody plants in which they are used in flavoring food dishes; the herbs could be leaves, stems or seeds. Nutritionally, the spices and herbs are significant in reducing the peroxidation of lipids, which are the changes (offflavor) in the nature and the chemical composition of lipids during the processing, preservation and the final preparation of foods [4]. Generally, spices and herbs prevent the lipid oxidation process due to the presence of natural antioxidants [5]-[7]. Spices and herbs have also antimicrobial properties that can help in the preservation of foods and more recently in animal feed. Nowadays, there is more pressure by consumers in food and feed industry in replacing synthetic preservatives by natural preservatives [8] [9]. Antimicrobial compounds in food, whether or not processed, can increase the shelf life by reducing the growth of microorganisms or by reducing their viability [10]-[12]. The exact chemical composition of herbs and spices have been reported to be greatly influenced by many factors such as part of the plant used, its vegetative state, environmental conditions, harvesting technique, etc. [13]. Recent review reported the variation in approximate composition of the essential oils in spices [8], however and to best of our knowledge, no study reported the variation in mineral and chemical composition of herbs and spices marketed in Jordan. The main objective of this research was to characterize the chemical and minerals composition and antimicrobial and anti fungal activities of the mostly used spices and herbs present in Jordanian market.

\section{Materials and Methods}

About $500 \mathrm{~g}$ of the investigated spices and herbs (Table 1) were purchased from the local markets, mainly in Irbid governorate in Jordan. All the spices were purchased on two different occasions within a two months period. All the purchased spices were ground to a fine powder using a laboratory mill to pass a $0.5 \mathrm{~mm}$ sieve and kept at $4^{\circ} \mathrm{C}$ in Ziploc plastic bags until analyzed. All spices were identified according to the label of the container.

Proximate Analysis: Moisture, ash, proteins, fat and crude fiber contents were determined according to the standard procedures outlined in Williams [14]. Total carbohydrate was calculated by difference according to Williams [14] procedure.

Minerals Analysis: The spice samples were ashed and the residue was dissolved in hydrochloric acid and quantitatively transferred into a volumetric flask. The volume was made up to $50 \mathrm{ml}$ using distilled deionized water. The concentration of the mineral elements ( $\mathrm{Ca}, \mathrm{Na}, \mathrm{K}, \mathrm{Cu}, \mathrm{Fe}, \mathrm{Mg}, \mathrm{Mn}$ and $\mathrm{Zn}$ ) was determined using atomic absorption spectrophotometer according to the method outlined by the Williams [14]. Phosphorous was determined according to the procedure reported by Fiske and Subbarow [15]. The averages were recorded and computed on dry weight basis.

Microbiological Analysis: All investigated spices were tested for total plate count, aerobic spore forming count and enumeration of yeast and mold according to the procedure described by Cousin [16] and Andrews [17].

Table 1. The investigated spices marketed in Jordan.

\begin{tabular}{ccc}
\hline Plant family & Scientific name & English name \\
Myrtaceae & Syzygium aromaticum L. & Cloves \\
Apiaceae & Coriadrum sativum L. & Coriander \\
Apiaceae & Cuminum cyminum L. \\
Zingiberaceae & Zingiber officinale Rosc. \\
Zingiberaceae & Elettaria cardamomum \\
Zingiberaceae & Curcuma longa L. \\
Anacardiaceae & Rhus coriaria L. \\
Lauraceae & Cinnamomin zeylanicum Blume \\
Apiaceae & Foeniculum vulgare Mill \\
Lauraceae & Laurus nobilis L. & Turmeric \\
Sumac
\end{tabular}


Statistical Analysis: The collected data were statistically analyzed using analysis of variance (ANOVA), using the general linear model procedure of SAS institute (2004). Data for each test were analyzed as a Completely Randomized Design (CRD). Differences among treatment means were separated using the Least Significant Differences (LSD) at $\mathrm{P} \leq 0.05$.

\section{Results and Discussion}

\subsection{Chemical Composition}

Data on the dry matter, ash, fat, protein, fiber and carbohydrates constituents in the investigated spices are shown in Table 2. Dry matter varied significantly among the spices, and ranged from 83.6\% (cloves) and 92.4\% (sumac). The ash contents were varied significantly among all the investigated spices, and ranged between $4.5 \%$ (cinnamon) and 10.4\% (sweet cumin). Cloves and coriander were not varied significantly and the ash values were $7.8 \%$ and $7.3 \%$, respectively. The dry matter and ash content of these spices were found to agree with data reported previously [3].

The fat contents varied significantly among the spices. Cinnamon, turmeric and green cardamom showed significantly the lowest values for the fat contents $(1.7 \%, 2.9 \%$, and $3.2 \%$ respectively), while the fat content for the sumac, cumin, sweet cumin and coriander had significantly the highest values (19.7\%, 15.5\%, 13.7\% and $11.6 \%$ respectively). These results are comparable with those reported by Kirk and Sawyer [3].

Protein levels of spices showed that all spices were significantly different. The protein values ranged between 2.9\% for sumac and $21.2 \%$ for cumin and these results were similar to values reported by Tashtush [18]. Furthermore, the protein contents for cloves, ginger, sweet laurel and green cardamom they were almost similar (9.3\%, 9.4\%, 9.7\% and 9.9\% respectively. Fiber contents also varied significantly among the spices and ranged between $25.78 \%$ (cumin) and 59.29\% (turmeric). In general, the outer protective coatings of many foods contain considerably more fiber than the softer [3]. As the fiber content increases with plants age, the fiber may be of value in assessing the maturity of legumes.

Carbohydrate levels were significantly different in the spices, the content ranged between $4.55 \%$ and $31 \%$. Cloves, sumac, cinnamon and green cardamom had significantly the highest values (31.0\%, 27.25\%, 24.49\% and $21.10 \%$, respectively). While the sweet cumin, coriander, turmeric and sweet laurel had significantly the lowest values (4.55\%, 9.9\%, $11.11 \%$ and $12.1 \%$, respectively).

Among all nutrient composition, fat contents in the current study had the highest variation $(\mathrm{CV}=57.09 \%)$ while dry matter content had the lowest variation $(\mathrm{CV}=3.12 \%)$. The variation in fat content suggests high variation in the essential oil content. Within same spices type, huge variations in essential oils have been reported to

Table 2. Gross chemical composition of spices marketed in Jordan.

\begin{tabular}{|c|c|c|c|c|c|c|}
\hline Spices & DM (\%) & Ash (\%) & Fat (\%) & Protein (\%) & Fiber (\%) & Carbohydrate (\%) \\
\hline Cloves & $83.6^{\mathrm{e}^{*}}$ & $7.8^{\mathrm{bc}}$ & $4.3^{\mathrm{f}}$ & $9.3^{\mathrm{de}}$ & $31.2^{\mathrm{ef}}$ & $31^{\mathrm{a}}$ \\
\hline Coriander & $90.8^{\mathrm{ab}}$ & $7.3^{\mathrm{cd}}$ & $11.6^{\mathrm{d}}$ & $14.9^{\mathrm{c}}$ & $47.1^{\mathrm{d}}$ & $9.9^{\mathrm{h}}$ \\
\hline Cumin & $90.4^{\mathrm{ab}}$ & $9.1^{\mathrm{ab}}$ & $15.5^{\mathrm{b}}$ & $21.2^{\mathrm{a}}$ & $25.7^{\mathrm{f}}$ & $18.8^{\mathrm{e}}$ \\
\hline Ginger & $89.1^{\mathrm{bc}}$ & $5.4^{\mathrm{e}}$ & $4.0^{\mathrm{f}}$ & $9.4^{\text {de }}$ & $52.1^{\mathrm{c}}$ & $18.1^{\mathrm{f}}$ \\
\hline Cardamom & $85.3^{\mathrm{de}}$ & $10.2^{\mathrm{a}}$ & $3.2^{\mathrm{gf}}$ & $9.9^{\mathrm{d}}$ & $40.9^{\mathrm{de}}$ & $21.1^{\mathrm{d}}$ \\
\hline Turmeric & $90.1^{\mathrm{ab}}$ & $8.4^{\mathrm{bc}}$ & $2.9^{g f}$ & $8.4^{\mathrm{e}}$ & $59.2^{\mathrm{a}}$ & $11.1^{\mathrm{h}}$ \\
\hline Sumac & $92.4^{\mathrm{a}}$ & $9.2^{\mathrm{ab}}$ & $19.7^{\mathrm{a}}$ & $2.9^{f}$ & $33.3^{\mathrm{e}}$ & $27.3^{\mathrm{b}}$ \\
\hline Cinnamon & $86.9^{\text {cd }}$ & $4.5^{\mathrm{e}}$ & $1.7^{\mathrm{g}}$ & $4.2^{\mathrm{f}}$ & $52.0^{\text {cd }}$ & $24.5^{\mathrm{c}}$ \\
\hline Cumin & $91.1^{\mathrm{ab}}$ & $10.4^{\mathrm{a}}$ & $13.7^{c}$ & $18.2^{\mathrm{b}}$ & $44.2^{\mathrm{d}}$ & $4.5^{\mathrm{i}}$ \\
\hline Laurel & $90.1^{\mathrm{ab}}$ & $5.7^{\mathrm{de}}$ & $5.9^{\mathrm{e}}$ & $9.7^{\mathrm{de}}$ & $56.7^{\mathrm{ab}}$ & $12.1^{\mathrm{g}}$ \\
\hline LSD at $\mathrm{P} \leq 0.05$ & 2.6 & 1.7 & 1.5 & 1.4 & 4.3 & 0.8 \\
\hline CV (\%) & 3.15 & 26.29 & 57.09 & 53.20 & 25.59 & 46.92 \\
\hline
\end{tabular}

${ }^{\mathrm{a}}$ Means are average of four replicates values are computed on dry weight basis. ${ }^{\mathrm{b}}$ Means with different letters in the same column are significantly different at $\mathrm{P} \leq 0.05$. 
exist between different locations [19]. For instance, Viuda-Martos et al. [8] reported that approximate composition of the essential oil such as Eugenyl acetate in clover varied from traces to 20\%.

\subsection{Minerals Analysis}

Minerals determination experiment was to study the nutritional value of spices, nine minerals had been inspected, which were the calcium, sodium, potassium, cupper, iron, phosphorus, magnesium, manganese and zinc. These minerals are regarded as the most significant minerals in a valuable food. Table 3 showed that cinnamon, sweet cumin and sweet laurel had the highest levels of calcium (299.1, 221.5 and $214.8 \mathrm{mg} / 100 \mathrm{~g}$, respectively) where turmeric and ginger observed the lowest values of calcium (13 and $66.8 \mathrm{mg} / 100 \mathrm{~g}$, respectively). Also, mineral analysis showed that the calcium contents varied significantly from one spice to another. For the sodium, sumac had the highest level of concentration $(85.1 \mathrm{mg} / 100 \mathrm{~g})$ where the coriander had the lowest concentration (11.9 mg/100g). Cumin (81.1 mg/100g), green cardamom (68.8 mg/100g) and cloves (61.6 mg/100g) had high concentrations of sodium while the cinnamon $(12 \mathrm{mg} / 100 \mathrm{~g})$ and sweet laurel $(15.1 \mathrm{mg} / 100 \mathrm{~g})$ had low contents of sodium. Potassium and the magnesium had higher concentrations than other minerals for all spices; sweet laurel had the highest concentration of potassium $(141.4 \mathrm{mg} / 100 \mathrm{~g})$, while the lowest concentration was found in cloves (111.6 mg/100g). Furthermore, the turmeric had the lowest amount of magnesium $(91.7 \mathrm{mg} / 100 \mathrm{~g})$ while the sumac $(254.1 \mathrm{mg} / 100 \mathrm{~g})$ and sweet cumin $(201.7 \mathrm{mg} / 100 \mathrm{~g})$ had the highest amount of magnesium. Copper, manganese, phosphorus and zinc had the lowest concentrations when comparing minerals in all spices. Copper was indicated by small portion of range in all spices $(0.3 \mathrm{mg} / 100 \mathrm{~g}-0.7 \mathrm{mg} / 100 \mathrm{~g})$, the highest concentration was shown by green cardamom and the lowest concentration was found in turmeric. Manganese content was found to be low and varied significantly among the spices. Cloves had the higher content $(20.9 \mathrm{mg} / 100 \mathrm{~g})$ whereas the lowest level found in sumac $(0.7 \mathrm{mg} / 100 \mathrm{~g})$. Phosphorous content showed a significant variation among the spices, and ranged from $0.7 \mathrm{mg} / 100 \mathrm{~g}$ (green cardamom) to $6.3 \mathrm{mg} / 100 \mathrm{~g}$ (coriander). Coriander and turmeric had significantly the highest phosphorous contents (6.3 and $6.1 \mathrm{mg} / 100 \mathrm{~g}$, respectively), cloves, cinnamon, sumac and cumin showed significantly lower level of phosphorous as compared to all other spices. Relatively, the spices were not rich in iron; their concentrations were ranged from $6.5 \mathrm{mg} / 100 \mathrm{~g}$ in sweet laurel to $20 \mathrm{mg} / 100 \mathrm{~g}$ in cumin. The concentrations of zinc were not varied significantly in most spices; they ranged from 3.7 (green cardamom) to $4.5 \mathrm{mg} / 100 \mathrm{~g}$ (ginger), while, the highest concentration of zinc was found in sumac $(5.7 \mathrm{mg} / 100 \mathrm{~g}$ ) and the lowest concentration was found in turmeric $(0.8 \mathrm{mg} / 100 \mathrm{~g})$.

Comparing between the minerals concentrations of some of the experimented spices such as cumin, sweet laurel, sumac and sweet cumin with Özcan [20] finding showed that the content of all minerals were higher in Özcan [20] finding for all tested spices except for the copper, zinc and manganese, which indicated a relatively

Table 3. Minerals content of spices marketed in Jordan.

\begin{tabular}{|c|c|c|c|c|c|c|c|c|c|}
\hline \multicolumn{10}{|c|}{ Minerals (mg/100g) } \\
\hline Spices & Ca & $\mathrm{Na}$ & $\mathbf{K}$ & $\mathbf{C u}$ & $\mathbf{F e}$ & $\mathbf{P}$ & Mg & Mn & $\mathbf{Z n}$ \\
\hline Cloves $^{\mathrm{b}}$ & $117.5^{\mathrm{ef}}$ & $61.6^{\mathrm{b}}$ & $111.6^{\mathrm{a}}$ & $0.4^{\mathrm{ab}}$ & $8.3^{\mathrm{de}}$ & $1.6^{\mathrm{ef}}$ & $196.8^{\mathrm{bc}}$ & $20.9^{\mathrm{a}}$ & $1.4^{\mathrm{cd}}$ \\
\hline Coriander & $89.7^{\mathrm{gf}}$ & $11.9^{\mathrm{d}}$ & $127.3^{\mathrm{a}}$ & $0.6^{\mathrm{ab}}$ & $12.2^{\mathrm{cd}}$ & $6.3^{\mathrm{a}}$ & $126.6^{\mathrm{ef}}$ & $17.9^{\mathrm{b}}$ & $4.0^{\mathrm{b}}$ \\
\hline Cumin & $161.7^{\mathrm{de}}$ & $81.1^{\mathrm{a}}$ & $133.3^{\mathrm{a}}$ & $0.6^{\mathrm{ab}}$ & $20.0^{\mathrm{a}}$ & $3.6^{\mathrm{cd}}$ & $166.9^{\mathrm{cd}}$ & $1.4^{\mathrm{d}}$ & $4.2^{\mathrm{b}}$ \\
\hline Ginger & $66.8^{\mathrm{g}}$ & $21.3^{\mathrm{cd}}$ & $127.2^{\mathrm{a}}$ & $0.6^{\mathrm{ab}}$ & $7.6^{\mathrm{de}}$ & $4.3^{\mathrm{bc}}$ & $100.8^{g f}$ & $1.5^{\mathrm{d}}$ & $4.5^{\mathrm{b}}$ \\
\hline Cardamom & $92.9^{g f}$ & $68.8^{\mathrm{ab}}$ & $127.4^{\mathrm{a}}$ & $0.7^{\mathrm{a}}$ & $18.6^{\mathrm{ab}}$ & $0.7^{\mathrm{f}}$ & $181.5^{\mathrm{bc}}$ & $9.9^{c}$ & $3.7^{\mathrm{b}}$ \\
\hline Turmeric & $13.0^{\mathrm{h}}$ & $29.8^{\mathrm{c}}$ & $115.2^{\mathrm{a}}$ & $0.3^{\mathrm{b}}$ & $17.7^{\mathrm{ab}}$ & $6.1^{\mathrm{ab}}$ & $91.7^{\mathrm{g}}$ & $1.6^{\mathrm{d}}$ & $0.8^{\mathrm{d}}$ \\
\hline Sumac & $175.0^{\mathrm{cd}}$ & $85.1^{\mathrm{a}}$ & $126.9^{\mathrm{a}}$ & $0.4^{\mathrm{ab}}$ & $14.6^{\mathrm{bc}}$ & $3.3^{\text {cde }}$ & $254.1^{\mathrm{a}}$ & $0.7^{\mathrm{d}}$ & $5.7^{\mathrm{a}}$ \\
\hline Cinnamon & $299.1^{\mathrm{a}}$ & $12.0^{\mathrm{d}}$ & $127.4^{\mathrm{a}}$ & $0.5^{\mathrm{ab}}$ & $8.1^{\mathrm{de}}$ & $2.1^{\mathrm{def}}$ & $140.3^{\mathrm{de}}$ & $8.7^{\mathrm{c}}$ & $1.3^{\mathrm{cd}}$ \\
\hline Cumin & $221.5^{\mathrm{b}}$ & $60.7^{\mathrm{b}}$ & $124.8^{\mathrm{a}}$ & $0.6^{\mathrm{ab}}$ & $8.2^{\mathrm{de}}$ & $4.0^{c}$ & $201.7^{\mathrm{b}}$ & $8.0^{c}$ & $3.8^{\mathrm{b}}$ \\
\hline Laurel & $214.8^{\mathrm{bc}}$ & $15.1^{\mathrm{cd}}$ & $141.4^{\mathrm{a}}$ & $0.4^{\mathrm{ab}}$ & $6.5^{\mathrm{e}}$ & $3.8^{\mathrm{cd}}$ & $80.6^{g}$ & $1.6^{\mathrm{d}}$ & $2.0^{c}$ \\
\hline LSD P $\leq 0.05$ & 44.8 & 17.6 & 36.3 & 0.3 & 4.8 & 1.8 & 33.7 & 2.6 & 0.9 \\
\hline CV (\%) & 63.59 & 69.13 & 23.92 & 28 & 46.7 & 52.2 & 44.87 & 104.2 & 57 \\
\hline
\end{tabular}

${ }^{\mathrm{a}}$ Means are average of four replicates and expressed in mg/100g as dry matter basis. ${ }^{* b}$ Means with different letters in the same column are significantly different at $\mathrm{P} \leq 0.05$. 
close content of minerals. Gallaher et al. [21] demonstrated the content of minerals in herbal tea, specifically, sodium, potassium, magnesium and calcium contents were higher for spices than the herbal tea whereas the copper, phosphorous, zinc and manganese minerals content in spices were comparable with values in herbal tea.

Aspilia Africana and Bryophlum pinnatum were examined for their minerals content by Okwu and Josiah [22]. The investigated spices showed higher levels of minerals when compared with Aspilia Africana and Bryophlum pinnatum plants except for the zinc, which was higher in Aspilia Africana and Bryophlum pinnatum plants than that in the current study. In this study, Mn content had the highest variation (CV $=104.28 \%)$ whereas $\mathrm{K}$ content had the lowest variation (CV $=23.92 \%)$.

\subsection{Microbiological Test}

Table 4 shows the microbiological analysis for the spices. Total plate, aerobic spore forming bacteria, yeast and mold count are presented in Table 4. Data showed that total plate count of cloves and sumac had the lowest colonies of bacteria ( $<10 \mathrm{CFU} / \mathrm{g}$ ), whereas, other spices had varied significantly; turmeric and sweet laurel had the highest level of total plate count $\left(3.5 \times 10^{4} \mathrm{CFU} / \mathrm{g}\right)$ for both spices. This data indicated that most of the spices had antimicrobial properties. Aerobic spore forming bacteria count varied significantly among the investigated spices, both cloves and sumac had the same and almost there was no growth for aerobic spore forming bacteria ( $<10 \mathrm{CFU} / \mathrm{g})$, turmeric had the highest count for aerobic spore forming bacteria $\left(5.0 \times 10^{4} \mathrm{CFU} / \mathrm{g}\right)$, while green cardamom had the lowest count among the spices $\left(2.3 \times 10^{3} \mathrm{CFU} / \mathrm{g}\right)$. The investigated spices when examined for yeast and mold; all spices except sweet laurel, green cardamom and coriander showed yeast and mold growth, the count per gram was found as $1.4 \times 10^{3}, 3.0 \times 10^{2}$ and $1.0 \times 10^{2} \mathrm{CFU} / \mathrm{g}$, respectively. Eugenol and cinnamaldehyde are essential oils extracted from spices and were recognized as antimicrobial compounds, mold inhibitors and prevent the spoilage of food products [20] [23]. During cleaning and processing of spices, progressive reduction in the numbers and types of microorganisms take place [24].

Guarino [25], Julseth and Deibel [26] reported that organisms remaining after physical treatment were generally mixtures of aerobic spore forming bacteria and common molds, other organisms found occasionally, usually in small numbers. Post-harvest treatment of spices ranges from primitive sun-drying and sifting to extensive methods of air-scrubbing, milling; fumigation and encapsulation of soluble extracts [25] [27] will reduced the microbial loads on cumin, coriander, chilies and black pepper. Yano et al. [28] observed that the use of spices in food may protect the risk of contamination by different types of bacteria. However, Burdock and Carabin [29] showed that oil extracted from Coriander seeds has wide-spectrum of antimicrobial activity. The normal amounts added to foods for flavoring was not sufficient to inhibit microbial growth. The conducted experiments indicated that the antimicrobial activity varied widely depending on the type of spice or herb, test medium and

Table 4. Total plate count, aerobic sporeforming count, yeast and mold count in spices marketed in Jordan.

\begin{tabular}{cccc}
\hline Spices & Total plate count & Sporeforming count & Yeast \& Mold \\
\hline Cloves $^{\mathrm{b}}$ & $<10^{\mathrm{f}}$ & $<10^{\mathrm{h}}$ & $\mathrm{ND}$ \\
Coriander & $1.3 \times 10^{3 \mathrm{~d}}$ & $1.0 \times 10^{3 \mathrm{f}}$ & $1.0 \times 10^{2 \mathrm{c}}$ \\
Cumin & $3.0 \times 10^{3 \mathrm{c}}$ & $1.2 \times 10^{3 \mathrm{f}}$ & $\mathrm{ND}$ \\
Ginger & $2.0 \times 10^{3 \mathrm{~cd}}$ & $2.0 \times 10^{3 \mathrm{~d}}$ & $\mathrm{ND}$ \\
Cardamom & $3.0 \times 10^{2 \mathrm{e}}$ & $2.3 \times 10^{2 \mathrm{~g}}$ & $\mathrm{ND}$ \\
Turmeric & $3.5 \times 10^{4 \mathrm{a}}$ & $5.0 \times 10^{4 \mathrm{a}}$ & $\mathrm{ND}$ \\
Sumac & $<10^{\mathrm{f}}$ & $<10^{\mathrm{h}}$ & $\mathrm{ND}$ \\
Cinnamon & $2.1 \times 10^{3 \mathrm{~cd}}$ & $2.0 \times 10^{3 \mathrm{de}}$ & $\mathrm{ND}$ \\
Cumin & $8.2 \times 10^{3 \mathrm{~b}}$ & $6.0 \times 10^{3 \mathrm{c}}$ & $1.4 \times 10^{3 \mathrm{a}}$ \\
Laurel & $3.5 \times 10^{4 \mathrm{a}}$ & $1.1 \times 10^{4 \mathrm{~b}}$ & 1.09 \\
\hline
\end{tabular}

${ }^{\mathrm{a}}$ Means are average of two replicates and expressed as CFU/g. ${ }^{\mathrm{b}}$ Means with different letters in the same column are significantly different at $\mathrm{P} \leq 0.05$. 
microorganism. However, the addition of herbs and spices helped in preserving foods held at refrigerated temperatures, at which the multiplication of microorganisms is slow. Cloves, coriander, ginger and cumin had antibacterial activity, which might be beneficial to preserve the risk of bacterial contamination in sea foods [28].

Results in the current investigation found to be in agreement with previously published data. Kossa et al. [30] found a strong antimicrobial activity of sumac oil extract against a broad spectrum of bacteria species, such as Bacillus cereus and Helicobacter pylori. These bacteria were found to be the most sensitive Gram-positive and Gram-negative bacteria. Interestingly, Gündüz et al. [31] found that sumac extract inhibited the activity of Salmonella typhimurium ATCC 13311 in tomatoes. Similar study conducted by Nasar-Abbas et al. [32] found that sumac inhibited the growth of 12 bacterial strains (6 Gram positives and 6 Gram negatives), mostly foodborne including pathogens. Deans et al. [33] found that oil extract from clove exhibited significant antimicrobial activity against 25 different genera of bacteria and 20 different isolates of Listeria monocytogenes.

\section{Acknowledgements}

Authors gratefully acknowledge the financial support of the Deanship of Scientific Research, Jordan University of Science and Technology, grant 69/2005.

\section{References}

[1] Hinneburg, I., Dorman, H.J.D. and Hiltunen, R. (2006) Antioxidant Activities of Extracts from Selected Culinary Herbs and Spices. Food Chemistry, 97, 122-129. http://dx.doi.org/10.1016/j.foodchem.2005.03.028

[2] Shrestha, S., et al. (2013) Flavonoids from the Fruits of Nepalese Sumac (Rhus parviflora) Attenuate Glutamate-Induced Neurotoxicity in HT22 Cells. Food Science and Biotechnology, 22, 895-902. http://dx.doi.org/10.1007/s10068-013-0161-2

[3] Kirk, S. and Sawyer, R. (1991) Pearson's Composition and Analysis of Foods. Longman Group Ltd.

[4] Shobana, S. and Naidu, K.A. (2000) Antioxidant Activity of Selected Indian Spices. Prostaglandins, Leukotrienes and Essential Fatty Acids, 62, 107-110. http://dx.doi.org/10.1054/plef.1999.0128

[5] Aruoma, O.I., et al. (1996) An Evaluation of the Antioxidant and Antiviral Action of Extracts of Rosemary and Provencal Herbs. Food and Chemical Toxicology, 34, 449-456. http://dx.doi.org/10.1016/0278-6915(96)00004-X

[6] Yanishlieva, N.V., Marinova, E. and Pokorný, J. (2006) Natural Antioxidants from Herbs and Spices. European Journal of Lipid Science and Technology, 108, 776-793. http://dx.doi.org/10.1002/ejlt.200600127

[7] Lee, K.A., et al. (2011) Antimicrobial and Antioxidative Effects of Onion Peel Extracted by the Subcritical Water. Food Science and Biotechnology, 20, 543-548. http://dx.doi.org/10.1007/s10068-011-0076-8

[8] Viuda-Martos, M., et al. (2010) Spices as Functional Foods. Critical Reviews in Food Science and Nutrition, 51, $13-28$. http://dx.doi.org/10.1080/10408390903044271

[9] Aliakbarlu, J., Sadaghiani, S.K. and Mohammadi, S. (2013) Comparative Evaluation of Antioxidant and Anti FoodBorne Bacterial Activities of Essential Oils from Some Spices Commonly Consumed in Iran. Food Science and Biotechnology, 22, 1487-1493. http://dx.doi.org/10.1007/s10068-013-0242-2

[10] Beuchat, L.R. and Golden, D.A. (1989) Antimicrobials Occurring Naturally in Foods. Food technology (USA).

[11] Appendini, P. and Hotchkiss, J.H. (2002) Review of Antimicrobial Food Packaging. Innovative Food Science \& Emerging Technologies, 3, 113-126. http://dx.doi.org/10.1016/S1466-8564(02)00012-7

[12] Qiu, Z.Y., Tang, M.L., Deng, G.J., et al. (2014) Antioxidant and Antigenotoxic Activities of Ethanol Extracts from Rhus chinensis Mill Leaves. Food Science and Biotechnology, 23, 1213-1221. http://dx.doi.org/10.1007/s10068-014-0166-5

[13] Cosentino, S., Tuberoso, C.I.G., Pisano, B., et al. (1999) In Vitro Antimicrobial Activity and Chemical Composition of Sardinian Thymus Essential Oils. Letters in Applied Microbiology, 29, 130-135. http://dx.doi.org/10.1046/j.1472-765X.1999.00605.x

[14] Williams, S. (1984) Official Methods of Analysis of the Association of Official Analytical Chemists. AOAC Inc., Arlington.

[15] Fiske, C.H. and Subbarow, Y. (1925) The Colorimetric Determination of Phosphorus. The Journal of Biological Chemistry, 66, 375-400.

[16] Cousin, M.A., Jay, J.M. and Vasavada, P.C. (1992) Psychrotrophic Microorganisms. Compendium of Methods for the Microbiological Examination of Foods, 3, 153-165.

[17] Andrews, W. (1992) Manual of Food Quality Control, 4. rev. 1: Microbiological Analysis. FAO Food and Nutrition 
Paper (FAO).

[18] Tashtush, S.H.I. (2007) The Levels of Phenolic Compounds, Anthocyanin, Antioxidants Activity, Gross Chemical Composition, Minerals Concentration and the Microbiological Status of Spices Marketed in Jordan. Deanship of Scientific Research.

[19] Sahib, N.G., et al. (2013) Coriander (Coriandrum sativum L.): A Potential Source of High-Value Components for Functional Foods and Nutraceuticals: A Review. Phytotherapy Research, 27, 1439-1456.

[20] Özcan, M. (2004) Mineral Contents of Some Plants Used as Condiments in Turkey. Food Chemistry, 84, 437-440. http://dx.doi.org/10.1016/S0308-8146(03)00263-2

[21] Gallaher, R.N., Gallaher, K., Marshall, A.J. and Marshall, A.C. (2006) Mineral Analysis of Ten Types of Commercially Available Tea. Journal of Food Composition and Analysis, 19, S53-S57. http://dx.doi.org/10.1016/j.jfca.2006.02.006

[22] Okwu, D.E. and Josiah, C. (2006) Evaluation of the Chemical Composition of Two Nigerian Medicinal Plants. African Journal of Biotechnology, 5, 357-361.

[23] Dighe, V.V., Gursale, A.A. and Charegaonkar, G.A. (2009) Quantitation of Eugenol, Cinnamaldehyde and Isoeugenol from Cinnamomum tamala Nees and Eberm. Leaf Powder and Cinnamomum zeylanicum Breyn Stem Bark Powder by LC. Chromatographia, 70, 1759-1762. http://dx.doi.org/10.1365/s10337-009-1382-7

[24] Pruthi, J.S. (1979) Spices and Condiments: Chemistry, Microbiology, Technology. Advances in Food Research, Supplement, 4, 1-449.

[25] Guarino, P.A. (1973) Microbiology of Spices, Herbs, and Related Materials. Spec Rep New York State Agricultural Experiment Station, Geneva, NY.

[26] Julseth, R.M. and Deibel, R.H. (1974) Microbial Profile of Selected Spices and Herbs at Import. Journal of Milk and Food Technology, 37, 414-419.

[27] Sgorbini, B., Bicchi, C., Cagliero, C., et al. (2015) Herbs and Spices: Characterization and Quantitation of Biologically-Active Markers for Routine Quality Control by Multiple Headspace Solid-Phase Microextraction Combined with Separative or Non-Separative Analysis. Journal of Chromatography A, 1376, 9-17. http://dx.doi.org/10.1016/j.chroma.2014.12.007

[28] Yano, Y., Satomi, M. and Oikawa, H. (2006) Antimicrobial Effect of Spices and Herbs on Vibrio Parahaemolyticus. International Journal of Food Microbiology, 111, 6-11. http://dx.doi.org/10.1016/j.ijfoodmicro.2006.04.031

[29] Burdock, G.A. and Carabin, I.G. (2009) Safety Assessment of Coriander (Coriandrum sativum L.) Essential Oil as a Food Ingredient. Food and Chemical Toxicology, 47, 22-34. http://dx.doi.org/10.1016/j.fct.2008.11.006

[30] Kossah, R., Zhang, H. and Chen, W. (2011) Antimicrobial and Antioxidant Activities of Chinese Sumac (Rhus typhina L.) Fruit Extract. Food Control, 22, 128-132. http://dx.doi.org/10.1016/j.foodcont.2010.06.002

[31] Gündüz, G.T., Gönül, Ş.A. and Karapinar, M. (2010) Efficacy of Sumac and Oregano in the Inactivation of Salmonella Typhimurium on Tomatoes. International Journal of Food Microbiology, 141, 39-44. http://dx.doi.org/10.1016/j.ijfoodmicro.2010.04.021

[32] Nasar-Abbas, S.M., Halkman, A.K. and Al-Haq, M.I. (2004) Inhibition of Some Foodborne Bacteria by Alcohol Extract of Sumac (Rhus coriaria L.). Journal of Food Safety, 24, 257-267. http://dx.doi.org/10.1111/j.1745-4565.2004.00506.x

[33] Deans, S.G., Noble, R.C., Hiltunen, R., et al. (1995) Antimicrobial and Antioxidant Properties of Syzygium aromaticum (L.) Merr. \& Perry: Impact upon Bacteria, Fungi and Fatty Acid Levels in Ageing Mice. Flavour and Fragrance Journal, 10, 323-328. 